\title{
Application of Chitosan in Bone and Dental Engineering
}

\author{
Alicia Aguilar 1,2, Naimah Zein ${ }^{1}$, Ezeddine Harmouch ${ }^{1}$, Brahim Hafdi ${ }^{1}$, Fabien Bornert 1,2,3, \\ Damien Offner 1,2,3, François Clauss 1,2,3, Florence Fioretti 1,2,3, Olivier Huck 1,2,3 (D), \\ Nadia Benkirane-Jessel $1,2, *$ D and Guoqiang Hua $1,2, *$ \\ 1 INSERM (French National Institute of Health and Medical Research), UMR 1260, Regenerative \\ Nanomedicine (RNM), FMTS, 11 Rue Humann, 67000 Strasbourg, France \\ 2 Université de Strasbourg, Faculté de Chirurgie Dentaire de Strasbourg, 8 Rue Sainte-Elisabeth, \\ 67000 Strasbourg, France \\ 3 Hôpitaux Universitaires de Strasbourg, Pôle de Médecine et de Chirurgie Bucco-Dentaires, \\ 67000 Strasbourg, France \\ * Correspondence: nadia.jessel@inserm.fr (N.B.-J.); g.hua@unistra.fr (G.H.)
}

Academic Editor: Jyh-Ping Chen

Received: 14 July 2019; Accepted: 19 August 2019; Published: 19 August 2019

\begin{abstract}
Chitosan is a deacetylated polysaccharide from chitin, the natural biopolymer primarily found in shells of marine crustaceans and fungi cell walls. Upon deacetylation, the protonation of free amino groups of the D-glucosamine residues of chitosan turns it into a polycation, which can easily interact with DNA, proteins, lipids, or negatively charged synthetic polymers. This positive-charged characteristic of chitosan not only increases its solubility, biodegradability, and biocompatibility, but also directly contributes to the muco-adhesion, hemostasis, and antimicrobial properties of chitosan. Combined with its low-cost and economic nature, chitosan has been extensively studied and widely used in biopharmaceutical and biomedical applications for several decades. In this review, we summarize the current chitosan-based applications for bone and dental engineering. Combining chitosan-based scaffolds with other nature or synthetic polymers and biomaterials induces their mechanical properties and bioactivities, as well as promoting osteogenesis. Incorporating the bioactive molecules into these biocomposite scaffolds accelerates new bone regeneration and enhances neovascularization in vivo.
\end{abstract}

Keywords: chitosan; bone engineering; regeneration; scaffold; periodontitis; dental pulp

\section{Introduction}

The first bioerodable artificial polymer-cell scaffold was implanted into animals 30 years ago [1]. Since then, tissue engineering has become an interdisciplinary field that applies the principles of engineering and life sciences toward the development of biological substitutes that restore, maintain, or improve tissue structure and function [2]. Several biomaterials have been used for the fabrication of the scaffolds, including natural materials derived from animals or plants (collagen, starch, gelatin, alginate, cellulose, fibrin, hyaluronan, and chitosan) and synthetic materials, such as bioactive ceramics and a wide range of synthetic polymers. However, the excellent bio-based 3-dimentional (3D) polymer scaffolds should not only be non-toxic, biocompatible, and biodegradable, but also be competent in promoting cell adhesion and retaining the metabolic functions of attached cells [3], as the 3D polymer scaffolds used in tissue engineering should mimic and provide an actual in vivo surrounding microenvironment for the incorporation of cells or growth factors to regenerate damaged tissues or organs [4]. The immunomodulatory biological effects of chitosan-based scaffold have also been described. In this regard, chitosan becomes one of the most commonly studied polymers in the scientific 
research, not only for biopharmaceutical and biomedical applications, but also for food science and technology [5].

\section{Results}

\subsection{Chitosan}

Chitosan (CS) is a linear, semi-crystalline polysaccharide composed of $\beta$-(1 $\rightarrow 4)$-2-acetamido -2-deoxy-b-D-glucan ( $n$-acetyl D-glucosamine) and $\beta$-(1 $\rightarrow 4)$-2-amino-2-deoxyb-D-glucan (D-glucosamine) units [6,7]. Its molecular weight ranges from 10 to over $1000 \mathrm{kDa}$. Chitosan is not extensively present in the environment, however, it can be easily produced via the alkaline $n$-deacetylation process of the natural biopolymer commonly found in the shells of marine crustaceans and in fungi cells walls-the chitin [8,9] (Figure 1). The deacetylation degree (DD) of chitosan, which gives an indication of the number of amino groups along the chains, is calculated as the ratio of D-glucosamine to the sum of D-glucosamine and $n$-acetyl D-glucosamine $[7,10,11]$.
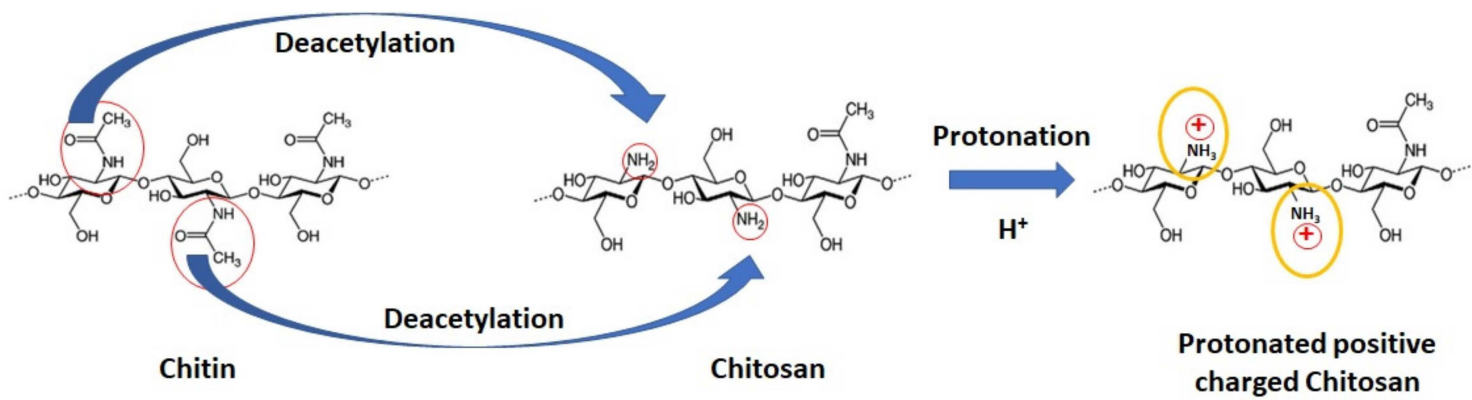

Figure 1. Structures for chitin, the noncharged form of chitosan, and protonated positive-charged chitosan.

Chitin is a white, hard, inelastic, nitrogeneous polysaccharide. It is hydrophobic and is not soluble in water and most organic solvents, except for hexafluroisopropanol, hexafluroacetone, and chloroalcohols [12]. This poor solubility of chitin is an extreme limit for its practical applications. However, the free amino groups of the D-glucosamine residues of chitosan, which could be protonated, provide a better solubility for chitosan by forming a non-Newtonian, shear-thinning fluid in most diluted acidic solutions at a pH below 6.5 (pKa value 6.3) [7,13] (Figure 1). With protonated amino groups, chitosan becomes a polycation and could subsequently form ionic complexes with a wide variety of natural or synthetic anionic species, for example, DNA, proteins, lipids, or negatively charged synthetic polymers such as poly(acrylic acid) [7,14,15].

Chitosan can be biodegraded into non-toxic residues by lysozyme or chitinase, which hydrolyses glucosamine-glucosamine, glucosamine- $n$-acetyl-glucosamine, and $n$-acetyl -glucosamine- $n$-acetyl -glucosamine linkages [16-18]. The rate and extent of chitosan's biodegradability in living organisms are highly related to the molecular mass of the polymer and its deacetylation degree (DD) $[19,20]$. The chitosan DD can also influence its biocompatibility. A higher DD increases the number of positive charges which increases the interaction between chitosan and cells, leading to an improved biocompatibility [21]. In addition, chitosan is a low-cost and economic natural biopolymer [22]. The price of chitin (3.6-6.0 US\$ $/ \mathrm{kg}$ )/chitosan (30-500 US\$/kg) are hundreds or thousands of times higher than the price of shell wastes $(0.05-0.15 \mathrm{US} \$ / \mathrm{kg})$ [23], while the production costs were around $1.70 \mathrm{US} \$ / \mathrm{kg}$ for chitin and $3.50 \mathrm{US} \$ / \mathrm{kg}$ for chitosan 40 years ago [24].

\subsection{Medical and Pharmaceutical Properties of Chitosan}

As a natural multifunctional polysaccharide, chitosan has been widely studied for biomedical, surgical, and tissue engineering and pharmaceutical application, thanks to its biocompatibility, biodegradability, and muco-adhesiveness. Chitosan is reported to be increasingly used in the United States as an over-the-counter cholesterol-lowering agent. Positively-charged deacetylated chitosan 
could bind negatively charged molecules, such as fatty acids, lipids, and bile acids, in the intestinal tract, excreting these molecules from the body [25]. Chitosan is thus considered as a promising candidate for obesity and hypercholesterolemia treatment [26]. Chitosan could be also used for wastewater treatment and beverage clarification because of its good chelating or binding capacity of protonable amino groups for various species, such as metal ions [27,28]. However, the most important medical and pharmaceutical applications of chitosan are drug delivery, wound dressings, and biocomposite scaffolds for tissue engineering.

\subsubsection{Drug Delivery}

The positively charged protonable amino group of the D-glucosamine residues of chitosan can interact with the negatively charged sialic acid residues of the glycoprotein which composes the mucus. Thus, the muco-adhesion is directly related to the DD of chitosan, with higher chitosan DD resulting in increased positive charges which enhance its muco-adhesive properties [29]. It has also been reported that chitosan can interact with the negative part of the cell membrane, enhancing the penetration of an active agent through the epithelium layer that contains tight junctions [30,31]. Consequently, owing to the muco-adhesion and enhanced penetration properties, chitosan is a suitable excipient to prepare oral, nasal, ocular, vaginal, and subcutaneous delivery forms and be used as a vaccine adjuvant or co-adjuvant to enhance the bioavailability and immunogenicity of antigens [32-34].

\subsubsection{Wound Dressings}

Wound healing is a particular biological phenomenon, which progresses through a series of inter-reliant and corresponding stages to regenerate the integrity of damaged tissue and replacement of lost tissue [35]. The hemostatic and antimicrobial properties of chitosan enable its application in wound dressings [35-37].

Again, as a natural positive-charged polysaccharide, protonable amino groups on the chitosan backbone electrostatically interact with the various negatively charged proteins and glycolipids on the surface of red blood cells (RBC). This interaction increases blood viscosity, activates platelet adhesion and aggregation, and enhances the transportation of platelets to the vascular wall for physiological hemostasis. Blood clots are formed by intensive aggregation of RBC around the wound site to quickly stop bleeding [38-41]. Thus, the number of positive charged amino groups on chitosan directly plays an important role in its hemostatic property.

The antimicrobial activity of chitosan has been demonstrated against different microorganisms both in vivo and in vitro, such as bacteria (either Gram-positive or Gram-negative), yeast, fungi, and algae, which makes chitosan good candidate as an antimicrobial agent in solution, film, and composite [35,42-46]. This antimicrobial property of chitosan has been related to the presence of its cationic nature. However, this antimicrobial activity could also depend on other intrinsic factors (for example, the type of chitosan or the degree of chitosan polymerization and deacetylation) and extrinsic factors (such as the live host, the microorganisms, and the environmental conditions). Until now, the antimicrobial activity of chitosan has not yet been fully understood.

\subsection{Chitosan-Based Scaffold Preparation}

The most common method to generate chitosan scaffolds is by freezing and lyophilizing chitosan solution. The spaces occupied by ice crystals formed in frozen chitosan solution are emptied during the sublimation, leading to the formation of pores. However, a precise control of temperature is required to form good pore structures $[47,48]$. Another method to form porous scaffolds is called salt leaching $[49,50]$. Salt crystals such as $\mathrm{NaCl}$ are used as porogens and put into a mold, and chitosan is then poured over the salt, penetrating into all the small spaces left between the salt crystals. The mold is then heated to melt the chitosan powder in an oven for a sufficient time. The chilled chitosan/ $\mathrm{NaCl}$ mixture is then separated from the mold and the salt is washed away by water or alcohol, generating open pores in the chitosan scaffolds. In addition, fibrous chitosan scaffolds are formed by 
electrospinning. An applied electric field causes the elongation of the chitosan drop and leads to the formation of long fibers ranging from the submicron level to several nanometers in diameter [51,52].

Besides the dried chitosan-based scaffold preparation discussed above, chitosan-based scaffolds could also be prepared as hydrogels [53]. A hydrogel is a network of the same or different types of cross-linked polymer chains with good water absorption capacity. Chemically cross-linked hydrogels are formed by covalent linking of chitosan macromers, in which the bond formation is irreversible. Covalent cross-linking can also be formed between polymers and a cross-linker [54], or via photopolymerization [55]. Another way to prepare chitosan-based hydrogel is by physical cross-linking through ionic interactions. Polyelectrolyte complex networks are formed via ionic interactions between positively charged chitosan and anions or other negatively charged polymers. Although chemically cross-linked chitosan-based hydrogels show better stability and resistance to environmental variables, physically cross-linked hydrogels are more biocompatible because of the lack of chemical cross-linkers.

\subsection{Chitosan-Based Scaffolds for Bone Regeneration}

Bone is a hard and highly functionalized connective tissue constituting the skeletal framework of the human body. It supports fleshy structures, protects vital organs, and is involved in various physiological functions such as the maintenance of phosphocalcic homeostasis [56,57]. After an injury, if the impairment is mild and the defect size is small, bone tissue has certain self-healing potential through osteogenic differentiation of bone marrow mesenchymal stem cells, bone neoformation, and neo-angiogenesis at the lesion site. For large-size bone defects, bone grafts are usually needed [58,59], however, these clinical procedures have many disadvantages [60].

In the context of bone engineering, the physiological inertness and low toxic effects of chitosan-based scaffolds have been demonstrated by numerous in vitro and in vivo studies (Table 1 ). In addition, no allergic and inflammatory reactions upon chitosan-based material implantation, injection, or topical application in the human body have been proven [61-63]; however, the use of chitosan as scaffold is limited by having reduced bioactivities and mechanical properties. This disadvantage has been overcome by mixing the chitosan scaffolds with other synthetic or natural polymers [poly(vinyl alcohol), poly- $\epsilon$-caprolactone, alginate, collagen, silk fibroin, etc.], biomaterials (hydroxyapatite, $\beta$-tricalcium phosphate, $\mathrm{SiO}_{2}$, etc.), or bioactive pharmacological molecules (bone morphogenetic protein 2 (BMP-2), vascular endothelial growth factor (VEGF), bisphosphonate, etc.).

Indeed, blending chitosan with most of the aforementioned polymer and/or biomaterials efficiently reinforces its mechanical properties and improves its bioactivities, such as increased protein absorption and increased biomineralization (Table 1). However, many of the published biocomposite scaffolds could not decrease the biodegradation rate of chitosan, which affects their long-term in vivo persistence (Table 1). Water retention ability is another parameter important for tissue engineering scaffolds, as the increased water retention ability of scaffold implanted in vivo could lead to the loosening and dislocation of the implant. As summarized in Table 1, most of the biocomposite scaffolds reported controls and decreased their water retention ability.

Most importantly, both in vitro and in vivo experiments demonstrated that all these chitosan-based biocomposite scaffolds are not toxic, and have very good properties of biocompatibility, osteoconductivity, and osteogenesis, promoting good cell proliferation and cell adhesion, causing an increase in new bone regeneration. Regarding more specific clinical applications of chitosan in alveolar bone and jawbone regeneration, several preclinical reports showed promising results, even for accelerating dental implant osseointegration and reconstructing critical size defects [64-67].

Over the last decade, the functionality of these chitosan-based biocomposite scaffolds have been enhanced by incorporating bioactive molecules into drug delivery systems. Therefore, bioactive molecules could be locally delivered with an adequate dose for a desired period, avoiding the drug release to non-target sites. Bone morphogenetic proteins (BMPs) are a group of growth factors originally discovered by their ability to induce bone and cartilage formation [68]. Transforming growth factor beta 
1 (TGF- $\beta 1$ ) is a polypeptide member of the transforming growth factor beta superfamily of cytokines, controlling cell growth, cell proliferation, and cell differentiation in many cell types. Studies have shown that chitosan-based biocomposite associated with either BMP2, BMP-7 or TGF- $\beta 1$ efficiently induced osteogenesis and promoted a large amount new bone formation compared with control or sham groups (see Table 1). Vascular endothelial growth factor (VEGF) is a signal protein stimulating the formation of blood vessels. Incorporating VEGF into chitosan-based biocomposite scaffolds induces angiogenesis and enhances neovascularization in bone healing (see Table 1).

\subsection{Chitosan-Based Application for Dental Engineering: The Case of Periodontal Regeneration}

Periodontitis is a chronic inflammatory disease induced by bacterial infection, affecting tooth-supporting tissues and leading to significant destruction of the periodontium (i.e., gingiva, alveolar bone, periodontal ligament, cement). Such a disease is common in the global population ( $>50 \%$ in the U.S. population) and is the main cause of tooth loss [69]. It is characterized by the development of the periodontal pocket and, in severe cases, of infrabony defects. Treatment of such lesions represent a challenge for the clinician [70,71]. Indeed, periodontal treatment aims to reduce the inflammation and to control the infection by chemical (antibiotics, antiseptics) and mechanical treatments (scaling and root planing). However, such a treatment strategy is associated mainly to wound repair, characterized by a long junctional epithelium. In most severe cases (probing pocket depth (PPD) $>5 \mathrm{~mm}$ ), non-surgical treatment alone could be insufficient in emphasizing the need of adjuvant therapy [72,73]. Therefore, the use of local delivery of active drugs or compounds has been suggested to target inflammation and infection, and in promoting tissue regeneration [74-77]. During the last decade, a specific interest was made towards the chitosan-based delivery system [78]. Several chitosan-based devices have been designed and evaluated in specific contexts, including in micro/nanoparticles, fibers, membrane, and gels [79-81]. Chitosan gels exhibit interesting physical properties that could be modulated by the concentration of chitosan. Indeed, it was shown that such chitosan-based gels (1-4\%) have an interesting viscosity to be injected within periodontal pockets. Most importantly, they can be used as a reliable vehicle to release active drugs at the disease site. While a sustained release could be considered ideal, it is important to note that the kinetic of release is a parameter that is also influenced by the percentage of chitosan [82]. Drugs, such as statins [83], doxycycline [84], or other antibiotics/antiseptics such as tetracyclines, have been incorporated in such devices [85-87].

Interestingly, adjuvant use of such drug-loaded scaffolds improved periodontal healing, emphasizing the interest in their use [78]. For instance, Chang et al. evaluated in vivo, in an experimental periodontitis murine model, the use of a chitosan-based hydrogel loaded with naringin, a natural compound with anti-inflammatory properties. They demonstrated the interesting properties of chitosan hydrogel, as its injection at the lesion site was associated with a burst release of the active compound during the acute phase of the inflammation, inducing an anti-inflammatory effect within periodontal tissues [88]. Such results might be explained by the controlled local delivery at the lesion site and the 3D characteristics of the chitosan scaffold.

Interestingly, it was also demonstrated that chitosan can potentialize the antibacterial effect of chlorhexidine [89], showing the intrinsic property of chitosan. 
Table 1. In vitro and in vivo studies of chitosan-based biocomposite scaffolds in bone engineering. VEGF = vascular endothelial growth factor, TGF- $\beta 1=$ transforming growth factor beta 1 .

\begin{tabular}{|c|c|c|c|c|}
\hline \multicolumn{5}{|c|}{ Chitosan-Based Biocomposite Scaffolds } \\
\hline Polymers and/or Biomaterials & $\begin{array}{l}\text { Bioactive } \\
\text { Molecule }\end{array}$ & Models & $\begin{array}{c}\text { Observations as Compared to the Properties of Chitosan } \\
\text { Polymer Scaffolds Alone }\end{array}$ & Reference \\
\hline & BMP-2 & $\begin{array}{l}\text { In vitro } \\
\text { In vivo }\end{array}$ & $\begin{array}{l}\text { No cytotoxicity and increased osteogenesis } \\
\text { No cytotoxicity, increased biomineralization, and increased } \\
\text { osteogenesis }\end{array}$ & [90] \\
\hline & $\begin{array}{l}\text { Recombinant } \\
\text { human BMP-2 }\end{array}$ & In vivo & Enhanced bone regeneration & [91] \\
\hline & & $\begin{array}{l}\text { In vitro } \\
\text { In vivo }\end{array}$ & $\begin{array}{l}\text { Increased biomineralization and increased osteogenesis } \\
\text { Improved and earlier bone regeneration }\end{array}$ & $\begin{array}{l}{[92]} \\
{[93]}\end{array}$ \\
\hline & & In vitro & No cytotoxicity, increased biomineralization & \\
\hline & & In vivo & Generation of a substantial amount of bone in rat cranium & [94] \\
\hline Hydroxyapatite & & In vivo & New bone tissue formation in rat & [95] \\
\hline Nano hydroxyapatite & & In vivo & $\begin{array}{c}\begin{array}{c}\text { Regeneration of segmental bone defects with cortical bone in } \\
\text { rabbit }\end{array}\end{array}$ & [96] \\
\hline Nano hydroxyapatite/Nano $\mathrm{ZrO}_{2} / \mathrm{Nano} \mathrm{CaZrO} 3$ & & In vitro & $\begin{array}{l}\text { No cytotoxicity, decreased water retention and increased } \\
\text { mechanical properties }\end{array}$ & [97] \\
\hline Calcium sulfate & & In vivo & Early bony consolidation & [98] \\
\hline $\mathrm{SiO}_{2}+\mathrm{ZrO}_{2}$ & & In vitro & $\begin{array}{c}\text { No cytotoxicity at low concentration, decreased water retention, } \\
\text { increased protein adsorption, biomineralization, and } \\
\text { biodegradation }\end{array}$ & [99] \\
\hline Bioactive glass + carbon nanotube & & In vitro & $\begin{array}{c}\text { No cytotoxicity, increased water retention, biodegradation, and } \\
\text { mechanical properties }\end{array}$ & [100] \\
\hline$\beta$-tricalcium phosphate & & In vitro & $\begin{array}{l}\text { No cytotoxicity at low concentration, decreased biodegradation, } \\
\text { and increased mechanical properties }\end{array}$ & [101] \\
\hline & & In vivo & Increased new bone formation & [102] \\
\hline$\gamma$-polyglutamic acid & & In vivo & Increased new bone formation & [103] \\
\hline Chondroitine sulfate + apatite & BMP-2 & In vivo & Enhanced bone regeneration & [104] \\
\hline Bioactive glass & & In vitro & $\begin{array}{l}\text { Decreased water retention, increased biomineralization, } \\
\text { biodegradation, and mechanical properties }\end{array}$ & [105] \\
\hline $\begin{array}{c}\text { Bioactive glass }+ \text { poly lactic-co-glycolic acid (PLGA) } \\
\text { nanoparticles }\end{array}$ & & In vitro & Decreased water retention, and increased mechanical properties & [106] \\
\hline Carbon nanotube & & In vitro & No cytotoxicity, increased biomineralization & [107] \\
\hline Keratin nanoparticles & & In vitro & $\begin{array}{l}\text { No cytotoxicity, increased protein adsorption and } \\
\text { biodegradation }\end{array}$ & {$[108]$} \\
\hline Glycerophosphate & & In vivo & Enhanced bone regeneration & [109] \\
\hline Glycerophosphate + graphene oxide & & In vitro & $\begin{array}{l}\text { No cytotoxicity, increased water retention, protein adsorption, } \\
\text { biomineralization, biodegradation, and osteogenesis }\end{array}$ & {$[110]$} \\
\hline
\end{tabular}


Table 1. Cont

\begin{tabular}{|c|c|c|c|c|c|}
\hline \multicolumn{6}{|c|}{ Chitosan-Based Biocomposite Scaffolds } \\
\hline \multicolumn{2}{|c|}{ Polymers and/or Biomaterials } & $\begin{array}{l}\text { Bioactive } \\
\text { Molecule }\end{array}$ & Models & $\begin{array}{c}\text { Observations as Compared to the Properties of Chitosan } \\
\text { Polymer Scaffolds Alone }\end{array}$ & Reference \\
\hline \multirow{2}{*}{\multicolumn{2}{|c|}{ poly- $\epsilon$-caprolactone }} & \multirow{2}{*}{ BMP-2 } & In vitro & No cytotoxicity & \multirow{2}{*}{ [111] } \\
\hline & & & In vivo & $\begin{array}{c}\text { Regeneration of both the subchondral bone and the cartilage in } \\
\text { large animal model }\end{array}$ & \\
\hline \multirow{5}{*}{\multicolumn{2}{|c|}{ Chitin + Nano $\mathrm{ZrO}_{2}$}} & \multirow{4}{*}{ BMP-2 } & In vitro & $\begin{array}{c}\text { No cytotoxicity, decreased water retention and biodegradation, } \\
\text { increased biomineralization and osteogenesis }\end{array}$ & [112] \\
\hline & & & In vivo & Enhanced bone regeneration & [113] \\
\hline & & & In vitro & No cytotoxicity, increased biomineralization and osteogenesis & \\
\hline & & & In vivo & No cytotoxicity, increased biomineralization and osteogenesis & [114] \\
\hline & & BMP-7 & In vivo & Accelerated regeneration of alveolar bone tissue & [115] \\
\hline \multirow[t]{6}{*}{ Collagen } & PLGA/Polyethylene glycol & \multirow[t]{2}{*}{ VEGF } & In vitro & $\begin{array}{c}\text { Induced angiogenesis } \\
\text { Induced }\end{array}$ & {$[116]$} \\
\hline & & & $\begin{array}{l}\text { In vivo } \\
\text { In vitro }\end{array}$ & $\begin{array}{l}\text { Induced angiogenesis and vascularization in rat } \\
\text { Controlled growth factor release rate }\end{array}$ & \multirow{2}{*}{ [117] } \\
\hline & PLGA & rhBMP-2 & In vivo & Enhanced bone formation and fast bone regeneration in dog & \\
\hline & $\begin{array}{l}\text { Chondroitine sulfate + } \\
\text { hydroxyapatite }\end{array}$ & & In vitro & $\begin{array}{l}\text { Secretion of higher level of receptor activator of nuclear factor } \\
\text { kappa-B ligand (RANKL) to mediate osteoclastogenesis }\end{array}$ & [118] \\
\hline & $\begin{array}{l}\text { Advanced platelet rich fibrin } \\
\text { (A-PRF) }\end{array}$ & & In vitro & $\begin{array}{l}\text { No cytotoxicity, increased biomineralization and mechanical } \\
\text { properties, decreased biodegradation }\end{array}$ & [119] \\
\hline & $\mathrm{Nano} \mathrm{SiO}_{2}$ & & In vitro & $\begin{array}{c}\text { No cytotoxicity, decreased water retention and mechanical } \\
\text { properties, increased protein adsorption, biomineralization, } \\
\text { biodegradation, and osteogenesis }\end{array}$ & [120] \\
\hline \multirow[t]{4}{*}{ Alginate } & Nano-sized hydroxyapatite & \multirow{4}{*}{ BMP-2 } & In vitro & $\begin{array}{c}\text { No cytotoxicity, increased biomineralization, osteogenesis, and } \\
\text { mechanical properties }\end{array}$ & [121] \\
\hline & Hydroxyapatite & & $\begin{array}{l}\text { In vitro } \\
\text { In vivo }\end{array}$ & $\begin{array}{l}\text { No cytotoxicity } \\
\text { Strong positive effect on bone formation in mice }\end{array}$ & [122] \\
\hline & & & In vitro & No cytotoxicity & \multirow{2}{*}{ [123] } \\
\hline & & & In vivo & $\begin{array}{c}\text { Great osteogenesis and reconstruction of critical size bone } \\
\text { defects }\end{array}$ & \\
\hline \multirow{3}{*}{ Silk fibroin } & Nano $\mathrm{ZrO}_{2}$ & & In vitro & $\begin{array}{c}\text { No cytotoxicity, increased water retention, biomineralization, } \\
\text { biodegradation, and mechanical properties }\end{array}$ & [124] \\
\hline & Hydroxyapatite & & In vitro & Increased biomineralization and osteogenesis & [125] \\
\hline & & TGF- $\beta 1$ & In vivo & $\begin{array}{c}\text { Biocompatibility and extensive osteoconductivity and } \\
\text { osteogenesis }\end{array}$ & {$[126]$} \\
\hline
\end{tabular}


Table 1. Cont

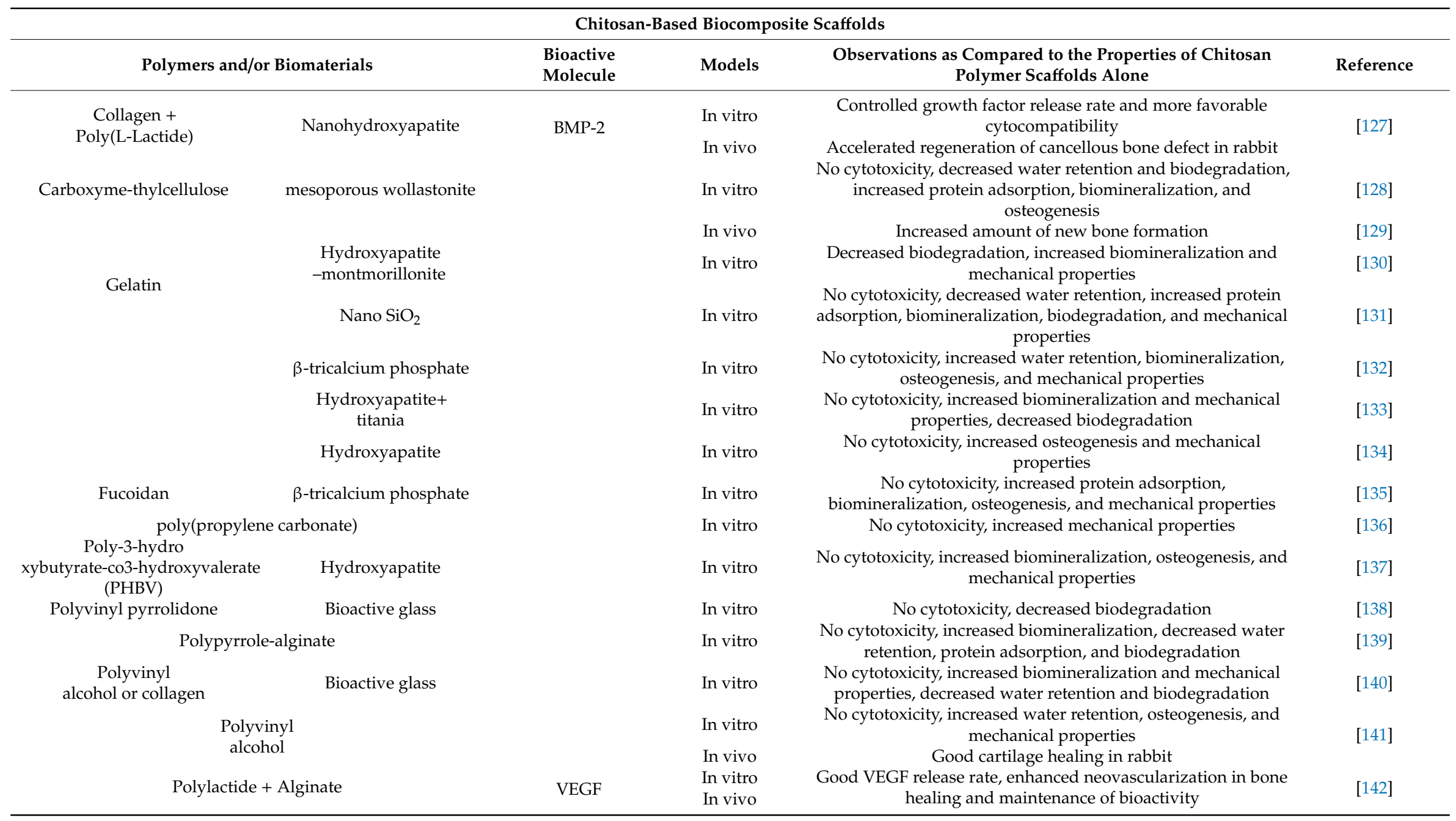




\subsection{Chitosan-Based Scaffold in Dental-Pulp Regeneration}

The endodontic space located in the heart of the tooth contains pulp, which is crucial for its vitality. This soft connective tissue contains collagen fibers, dental stem cells, vascularization, and innervation surrounded by dentin. This pulp-dentin complex is very reactive and, after significant aggression, the painful inflammatory reaction of the pulp-dentin complex is often hard to dissipate and leads to pulp necrosis. The conventional endodontic treatment is drastic, as all tissues are removed whatever their regenerative potentials. Recently, regenerative strategies targeting regeneration of pulp connective-tissue, dentin, radicular edification, vascularization, and innervation were developed [143]. Scaffolds represent the key element of the endodontic treatment. They are essential for delivering active molecules and for carrying competent cells within the endodontic compartment. They must have an adequate viscosity, allowing their injection in the whole root canal system, and porosity, which is crucial for cell colonization.

Recently, chitosan-based scaffolds have been developed for this purpose [144]. They are favorable, not only for pulp regeneration, but also for dentin formation because of their capacities to induce mineralization. Indeed, chitosan scaffolds containing $\beta$-tricalcium phosphate promoted a high expression of mineralization markers, such as osteopontin and alkaline phosphatase, and dentin formation by human periodontal ligament cells (HPLCs) [145]. In addition, several recent reports demonstrated that chitosan-based scaffolds promoted the proliferation, migration, and odontoblastic differentiation of dental pulp stem cells and mesenchymal stem cells both in vitro and in vivo [146-149] (Table 2). The use of chitosan as a vector for antimicrobials has also been tested with interesting outcomes [150].

Table 2. Chitosan-based scaffold in dental-pulp regeneration.

\begin{tabular}{|c|c|c|c|c|}
\hline \multicolumn{5}{|c|}{ Chitosan-Based Biocomposite Scaffolds } \\
\hline $\begin{array}{l}\text { Polymers and/or } \\
\text { Biomaterials }\end{array}$ & Bioactive Molecule & Model & Observations & Reference \\
\hline $\begin{array}{l}\beta \text {-tricalcium } \\
\text { phosphate }\end{array}$ & & In vitro & $\begin{array}{l}\text { - Upregulated expressions of alkaline phosphatase } \\
\text { (ALP) and osteopontin (OPN) } \\
\text { - } \quad \text { Release of BMP-7 gene }\end{array}$ & [145] \\
\hline Collagen & BMP-7 & In vivo & $\begin{array}{l}\text { Dental pulp stem cells (DPSC) differentiation into } \\
\text { odontoblast-like cells in vitro and in vivo }\end{array}$ & [146] \\
\hline Calcium-aluminate & $\begin{array}{l}\text { 1 } \alpha, 25 \text {-dihydroxyvitamin } \\
\text { D3 }(1 \alpha, 25 \mathrm{VD})\end{array}$ & In vitro & $\begin{array}{l}\text { - Increased odontoblastic phenotype expression } \\
\text { - Cell migration }\end{array}$ & [147] \\
\hline Fibrin & & In vitro & $\begin{array}{l}\text { - Potent antibacterial effect } \\
\text { - Similar dental pulp-mesenchymal stem cells } \\
\text { (DP-MSC) viability, fibroblast-like morphology, } \\
\text { proliferation rate } \\
\text { - Type I/III collagen production capacity. }\end{array}$ & [148] \\
\hline $\begin{array}{l}\text { Silver-doped } \\
\text { bioactive glass }\end{array}$ & & In vitro & $\begin{array}{l}\text { - The proliferation of dental pulp cells (DPC) is } \\
\text { not affected } \\
\text { - } \quad \text { Decrease of inflammation } \\
\text { - } \quad \text { Inhibition of Streptococcus mutans and Lactobacillus } \\
\text { casei growth }\end{array}$ & [149] \\
\hline
\end{tabular}

\section{Conclusions}

As a positive-charged, low-cost natural polymer with good biodegradability and biocompatibility, as well as having non-toxic, muco-adhesive, hemostatic, and antimicrobial properties, chitosan is a good candidate for biomedical and biopharmaceutical research. Consequently, chitosan-based scaffolds have been widely studied and applied in tissue engineering for the last two decades. Indeed, blending chitosan with other natural or synthetic polymers and/or biomaterials could efficiently control the porosity and water retention of these biocomposite scaffolds, reduce their biodegradation rate, enhance their bioactivity and biocompatibility, and increase their mechanical properties. Importantly, as demonstrated in both in vitro and in vivo studies, most of these biocomposite scaffolds have no cytotoxicity and promote the attachment and proliferation of cells for tissue repair. In addition, the 
combination of bioactive molecules with these chitosan-based biocomposite scaffolds could not only promote the proliferation and differentiation of stem cells and accelerate the tissue regeneration, but also induce angiogenesis and vascularization in different animal models, which could consequently be used in human clinical trials.

Author Contributions: A.A., F.B., F.C., F.F., O.H., N.B.-J., and G.H. conceived and designed the review; A.A., N.Z., E.H., B.H., F.B., D.O., F.C., F.F., O.H., N.B.-J., and G.H. studied the literature; A.A., N.Z., F.B., D.O., F.C., F.F., O.H., N.B.-J., and G.H. wrote the manuscript.

Funding: This research was supported by the Agence Nationale de la Recherche (ANR), Institut National de la Santé et de la Recherche Médicale (INSERM), and Faculté de Chirurgie-Dentaire (Université de Strasbourg).

Conflicts of Interest: The authors declare no conflict of interest.

\section{References}

1. Vacanti, J.P.; Morse, M.A.; Saltzman, W.M.; Domb, A.J.; Perez-Atayde, A.; Langer, R. Selective cell transplantation using bioabsorbable artificial polymers as matrices. J. Pediatr. Surg. 1988, 23, 3-9. [CrossRef]

2. Langer, R.; Vacanti, J.P. Tissue engineering. Science 1993, 260, 920-926. [CrossRef] [PubMed]

3. Chan, B.P.; Leong, K.W. Scaffolding in tissue engineering: General approaches and tissue-specific considerations. Eur. Spine. J. 2008, 17, 467-479. [CrossRef] [PubMed]

4. Loh, Q.L.; Choong, C. Three-Dimensional Scaffolds for Tissue Engineering Applications: Role of Porosity and Pore Size. Tissue Eng. Part B Rev. 2013, 19, 485-502. [CrossRef] [PubMed]

5. Bellich, B.; D'Agostino, I.; Semeraro, S.; Gamini, A.; Cesàro, A. "The Good, the Bad and the Ugly" of Chitosans. Mar. Drugs 2016, 14, 99. [CrossRef] [PubMed]

6. Deepthi, S.; Venkatesan, J.; Kim, S.-K.; Bumgardner, J.D.; Jayakumar, R. An overview of chitin or chitosan/nano ceramic composite scaffolds for bone tissue engineering. Int. J. Biol. Macromol. 2016, 93, 1338-1353. [CrossRef] [PubMed]

7. Croisier, F.; Jérôme, C. Chitosan-based biomaterials for tissue engineering. Eur. Polym. J. 2013, 49, 780-792. [CrossRef]

8. Aranaz, I.; Harris, R.; Heras, A. Chitosan Amphiphilic Derivatives. Chem. Appl. Curr. Org. Chem. 2010, 308-330. [CrossRef]

9. Dash, M.; Chiellini, F.; Ottenbrite, R.M.; Chiellini, E. Chitosan-A versatile semi-synthetic polymer in biomedical applications. Prog. Polym. Sci. 2011, 36, 981-1014. [CrossRef]

10. Madihally, S.V.; Matthew, H.W. Porous chitosan scaffolds for tissue engineering. Biomaterials 1999, 20, 1133-1142. [CrossRef]

11. Acosta, N.; Jiménez, C.; Borau, V.; Heras, A. Extraction and characterization of chitin from crustaceans. Biomass Bioenergy 1993, 5, 145-153. [CrossRef]

12. Synowiecki, J.; Al-Khateeb, N.A. Production, properties, and some new applications of chitin and its derivatives. Crit. Rev. Food Sci. Nutr. 2003, 43, 145-171. [CrossRef] [PubMed]

13. Yi, H.; Wu, L.-Q.; Bentley, W.E.; Ghodssi, R.; Rubloff, G.W.; Culver, J.N.; Payne, G.F. Biofabrication with chitosan. Biomacromolecules 2005, 6, 2881-2894. [CrossRef] [PubMed]

14. Pavinatto, F.J.; Caseli, L.; Oliveira, O.N. Chitosan in nanostructured thin films. Biomacromolecules 2010, 11, 1897-1908. [CrossRef] [PubMed]

15. Takahashi, T.; Takayama, K.; Machida, Y.; Nagai, T. Characteristics of polyion complexes of chitosan with sodium alginate and sodium polyacrylate. Int. J. Pharm. 1990, 61, 35-41. [CrossRef]

16. Kean, T.; Thanou, M. Biodegradation, biodistribution and toxicity of chitosan. Adv. Drug Deliv. Rev. 2010, 62, 3-11. [CrossRef] [PubMed]

17. Baldrick, P. The safety of chitosan as a pharmaceutical excipient. Regul. Toxicol. Pharm. 2010, 56, $290-299$. [CrossRef] [PubMed]

18. Huet, J.; Rucktooa, P.; Clantin, B.; Azarkan, M.; Looze, Y.; Villeret, V.; Wintjens, R. X-ray structure of papaya chitinase reveals the substrate binding mode of glycosyl hydrolase family 19 chitinases. Biochemistry 2008, 47, 8283-8291. [CrossRef] [PubMed]

19. Yang, Y.M.; Hu, W.; Wang, X.D.; Gu, X.S. The controlling biodegradation of chitosan fibers by N-acetylation in vitro and in vivo. J. Mater. Sci Mater. Med. 2007, 18, 2117-2121. [CrossRef] 
20. Xu, J.; McCarthy, S.P.; Gross, R.A.; Kaplan, D.L. Chitosan Film Acylation and Effects on Biodegradability. Macromolecules 1996, 29, 3436-3440. [CrossRef]

21. Chatelet, C.; Damour, O.; Domard, A. Influence of the degree of acetylation on some biological properties of chitosan films. Biomaterials 2001, 22, 261-268. [CrossRef]

22. Kadouche, S.; Farhat, M.; Lounici, H.; Fiallo, M.; Sharrock, P.; Mecherri, M.; Hadioui, M. Low Cost Chitosan Biopolymer for Environmental Use Made from Abundant Shrimp Wastes. Waste Biomass Valor. 2017, 8, 401-406. [CrossRef]

23. Pichyangkura, R. Application of chitin-chitosan from marine by-products in Thailand. In The FFTC-KU Joint Seminar on "Improved Utilization of Fishery By-product as Potential Nutraceuticals and Functional Foods"; Kasetsart University: Bangkok, Thailand, 2014; pp. 190-194.

24. Roberts, G.A.F. Thirty years of progress in chitin and chitosan. Prog. Chem. Appl. Chitin. Its Deriv. 2018, 13, 7-15.

25. Tapola, N.S.; Lyyra, M.L.; Kolehmainen, R.M.; Sarkkinen, E.S.; Schauss, A.G. Safety aspects and cholesterol-lowering efficacy of chitosan tablets. J. Am. Coll. Nutr. 2008, 27, 22-30. [CrossRef] [PubMed]

26. Baker, W.L.; Tercius, A.; Anglade, M.; White, C.M.; Coleman, C.I. A meta-analysis evaluating the impact of chitosan on serum lipids in hypercholesterolemic patients. Ann. Nutr. Metab. 2009, 55, 368-374. [CrossRef] [PubMed]

27. Rytwo, G.; Lavi, R.; Rytwo, Y.; Monchase, H.; Dultz, S.; König, T.N. Clarification of olive mill and winery wastewater by means of clay-polymer nanocomposites. Sci. Total Env. 2013, 442, 134-142. [CrossRef] [PubMed]

28. Rytwo, G. The use of clay-polymer nanocomposites in wastewater pretreatment. Scientific World J. 2012, 2012, 498503. [CrossRef]

29. He, P.; Davis, S.S.; Illum, L. In vitro evaluation of the mucoadhesive properties of chitosan microspheres. Int. J. Pharm. 1998, 166, 75-88. [CrossRef]

30. Yeh, T.-H.; Hsu, L.-W.; Tseng, M.T.; Lee, P.-L.; Sonjae, K.; Ho, Y.-C.; Sung, H.-W. Mechanism and consequence of chitosan-mediated reversible epithelial tight junction opening. Biomaterials 2011, 32, 6164-6173. [CrossRef]

31. Smith, J.; Wood, E.; Dornish, M. Effect of chitosan on epithelial cell tight junctions. Pharm. Res. 2004, 21, 43-49. [CrossRef]

32. Van der Lubben, I.M.; Kersten, G.; Fretz, M.M.; Beuvery, C.; Coos Verhoef, J.; Junginger, H.E. Chitosan microparticles for mucosal vaccination against diphtheria: Oral and nasal efficacy studies in mice. Vaccine 2003, 21, 1400-1408. [CrossRef]

33. Slütter, B.; Bal, S.M.; Que, I.; Kaijzel, E.; Löwik, C.; Bouwstra, J.; Jiskoot, W. Antigen-adjuvant nanoconjugates for nasal vaccination: An improvement over the use of nanoparticles? Mol. Pharm. 2010, 7, 2207-2215. [CrossRef]

34. Bal, S.M.; Slütter, B.; Verheul, R.; Bouwstra, J.A.; Jiskoot, W. Adjuvanted, antigen loaded N-trimethyl chitosan nanoparticles for nasal and intradermal vaccination: Adjuvant-and site-dependent immunogenicity in mice. Eur. J. Pharm. Sci. 2012, 45, 475-481. [CrossRef]

35. Boateng, J.S.; Matthews, K.H.; Stevens, H.N.E.; Eccleston, G.M. Wound healing dressings and drug delivery systems: A review. J. Pharm. Sci. 2008, 97, 2892-2923. [CrossRef]

36. Hurler, J.; Skalko-Basnet, N. Potentials of chitosan-based delivery systems in wound therapy: Bioadhesion study. J. Funct. Biomater. 2012, 3, 37-48. [CrossRef]

37. Okamoto, Y.; Yano, R.; Miyatake, K.; Tomohiro, I.; Shigemasa, Y.; Minami, S. Effects of chitin and chitosan on blood coagulation. Carbohydr. Polym. 2003, 53, 337-342. [CrossRef]

38. Hu, Z.; Zhang, D.-Y.; Lu, S.-T.; Li, P.-W.; Li, S.-D. Chitosan-Based Composite Materials for Prospective Hemostatic Applications. Mar. Drugs 2018, 16, 273. [CrossRef]

39. Huang, Y.; Feng, L.; Zhang, Y.; He, L.; Wang, C.; Xu, J.; Wu, J.; Kirk, T.B.; Guo, R.; Xue, W. Hemostasis mechanism and applications of N-alkylated chitosan sponge. Polym. Adv. Technol. 2017, 28, 1107-1114. [CrossRef]

40. Chou, T.-C.; Fu, E.; Wu, C.-J.; Yeh, J.-H. Chitosan enhances platelet adhesion and aggregation. Biochem. Biophys. Res. Commun. 2003, 302, 480-483. [CrossRef]

41. Sagnella, S.; Mai-Ngam, K. Chitosan based surfactant polymers designed to improve blood compatibility on biomaterials. Colloids Surf. B Biointerfaces 2005, 42, 147-155. [CrossRef] 
42. Ahmed, S.; Ikram, S. Chitosan Based Scaffolds and Their Applications in Wound Healing. Achiev. Life Sci. 2016, 10, 27-37. [CrossRef]

43. Choi, B.K.; Kim, K.Y.; Yoo, Y.J.; Oh, S.J.; Choi, J.H.; Kim, C.Y. In vitro antimicrobial activity of a chitooligosaccharide mixture against Actinobacillus actinomycetemcomitans and Streptococcus mutans. Int. J. Antimicrob. Agents 2001, 18, 553-557. [CrossRef]

44. Ikinci, G.; Senel, S.; Akincibay, H.; Kaş, S.; Erciş, S.; Wilson, C.G.; Hincal, A.A. Effect of chitosan on a periodontal pathogen Porphyromonas gingivalis. Int. J. Pharm. 2002, 235, 121-127. [CrossRef]

45. Savard, T.; Beaulieu, C.; Boucher, I.; Champagne, C.P. Antimicrobial action of hydrolyzed chitosan against spoilage yeasts and lactic acid bacteria of fermented vegetables. J. Food Prot. 2002, 65, 828-833. [CrossRef]

46. Martínez-Camacho, A.P.; Cortez-Rocha, M.O.; Ezquerra-Brauer, J.M.; Graciano-Verdugo, A.Z.; Rodriguez-Félix, F.; Castillo-Ortega, M.M.; Yépiz-Gómez, M.S.; Plascencia-Jatomea, M. Chitosan composite films: Thermal, structural, mechanical and antifungal properties. Carbohydr. Polym. 2010, 82, 305-315. [CrossRef]

47. Ruiz-Caro, R.; Veiga-Ochoa, M.D. Characterization and dissolution study of chitosan freeze-dried systems for drug controlled release. Molecules 2009, 14, 4370-4386. [CrossRef]

48. Keller, L.; Regiel-Futyra, A.; Gimeno, M.; Eap, S.; Mendoza, G.; Andreu, V.; Wagner, Q.; Kyzioł, A.; Sebastian, V.; Stochel, G.; et al. Chitosan-based nanocomposites for the repair of bone defects. Nanomedicine 2017, 13, 2231-2240. [CrossRef]

49. Lim, J.I.; Lee, Y.-K.; Shin, J.-S.; Lim, K.-J. Preparation of interconnected porous chitosan scaffolds by sodium acetate particulate leaching. J. Biomater. Sci. Polym. Ed. 2011, 22, 1319-1329. [CrossRef]

50. Pezeshki-Modaress, M.; Rajabi-Zeleti, S.; Zandi, M.; Mirzadeh, H.; Sodeifi, N.; Nekookar, A.; Aghdami, N. Cell-loaded gelatin/chitosan scaffolds fabricated by salt-leaching/lyophilization for skin tissue engineering: In vitro and in vivo study. J. Biomed. Mater. Res. A 2014, 102, 3908-3917. [CrossRef]

51. Geng, X.; Kwon, O.-H.; Jang, J. Electrospinning of chitosan dissolved in concentrated acetic acid solution. Biomaterials 2005, 26, 5427-5432. [CrossRef]

52. Dahlin, R.L.; Kasper, F.K.; Mikos, A.G. Polymeric nanofibers in tissue engineering. Tissue Eng. Part. B Rev. 2011, 17, 349-364. [CrossRef]

53. Ahmadi, F.; Oveisi, Z.; Samani, S.M.; Amoozgar, Z. Chitosan based hydrogels: Characteristics and pharmaceutical applications. Res. Pharm. Sci. 2015, 10, 1-16.

54. Bhattarai, N.; Gunn, J.; Zhang, M. Chitosan-based hydrogels for controlled, localized drug delivery. Adv. Drug Deliv. Rev. 2010, 62, 83-99. [CrossRef]

55. Chen, R.; Chen, Q.; Huo, D.; Ding, Y.; Hu, Y.; Jiang, X. In situ formation of chitosan-gold hybrid hydrogel and its application for drug delivery. Colloids Surf B Biointerfaces 2012, 97, 132-137. [CrossRef]

56. Walsh, J.S. Normal bone physiology, remodelling and its hormonal regulation. Surg. (Oxf) 2015, 33, 1-6. [CrossRef]

57. Arvidson, K.; Abdallah, B.M.; Applegate, L.A.; Baldini, N.; Cenni, E.; Gomez-Barrena, E.; Granchi, D.; Kassem, M.; Konttinen, Y.T.; Mustafa, K.; et al. Bone regeneration and stem cells. J. Cell Mol. Med. 2011, 15, 718-746. [CrossRef]

58. Loi, F.; Córdova, L.A.; Pajarinen, J.; Lin, T.; Yao, Z.; Goodman, S.B. Inflammation, fracture and bone repair. Bone 2016, 86, 119-130. [CrossRef]

59. Gómez-Barrena, E.; Rosset, P.; Lozano, D.; Stanovici, J.; Ermthaller, C.; Gerbhard, F. Bone fracture healing: Cell therapy in delayed unions and nonunions. Bone 2015, 70, 93-101. [CrossRef]

60. Rogers, G.F.; Greene, A.K. Autogenous bone graft: basic science and clinical implications. J. Craniofac. Surg. 2012, 23, 323-327. [CrossRef]

61. Waibel, K.H.; Haney, B.; Moore, M.; Whisman, B.; Gomez, R. Safety of chitosan bandages in shellfish allergic patients. Mil. Med. 2011, 176, 1153-1156. [CrossRef]

62. Jiang, T.; Ji, H.; Zhang, L.; Wang, Y.; Zhou, H. Chitosan Oligosaccharide Exerts Anti-Allergic Effect against Shrimp Tropomyosin-Induced Food Allergy by Affecting Th1 and Th2 Cytokines. Int. Arch. Allergy Immunol. 2019, 1-7. [CrossRef]

63. Azuma, K.; Osaki, T.; Minami, S.; Okamoto, Y. Anticancer and anti-inflammatory properties of chitin and chitosan oligosaccharides. J. Funct. Biomater. 2015, 6, 33-49. [CrossRef] 
64. Bhattarai, G.; Lee, Y.-H.; Lee, M.-H.; Park, I.-S.; Yi, H.-K. Insulin-like growth factor binding protein-3 affects osteogenic efficacy on dental implants in rat mandible. Mater. Sci. Eng. C Mater. Biol. Appl. 2015, 55, 490-496. [CrossRef]

65. Bhattarai, G.; Lee, Y.H.; Lee, M.H.; Yi, H.K. Gene delivery of c-myb increases bone formation surrounding oral implants. J. Dent. Res. 2013, 92, 840-845. [CrossRef]

66. Lee, Y.-H.; Kim, J.-S.; Kim, J.-E.; Lee, M.-H.; Jeon, J.-G.; Park, I.-S.; Yi, H.-K. Nanoparticle mediated PPAR $\gamma$ gene delivery on dental implants improves osseointegration via mitochondrial biogenesis in diabetes mellitus rat model. Nanomedicine 2017, 13, 1821-1832. [CrossRef]

67. Li, H.; Ji, Q.; Chen, X.; Sun, Y.; Xu, Q.; Deng, P.; Hu, F.; Yang, J. Accelerated bony defect healing based on chitosan thermosensitive hydrogel scaffolds embedded with chitosan nanoparticles for the delivery of BMP2 plasmid DNA. J. Biomed. Mater. Res. A 2017, 105, 265-273. [CrossRef]

68. Bleuming, S.A.; He, X.C.; Kodach, L.L.; Hardwick, J.C.; Koopman, F.A.; ten Kate, F.J.; van Deventer, S.J.H.; Hommes, D.W.; Peppelenbosch, M.P.; Offerhaus, G.J.; et al. Bone Morphogenetic Protein Signaling Suppresses Tumorigenesis at Gastric Epithelial Transition Zones in Mice. Cancer Res. 2007, 67, 8149-8155. [CrossRef]

69. Kinane, D.F.; Stathopoulou, P.G.; Papapanou, P.N. Periodontal diseases. Nat. Rev. Dis. Primers 2017, 3, 17038. [CrossRef]

70. Cortellini, P.; Tonetti, M.S. Clinical concepts for regenerative therapy in intrabony defects. Periodontol. 2000 2015, 68, 282-307. [CrossRef]

71. Cortellini, P.; Tonetti, M.S. Focus on intrabony defects: Guided tissue regeneration. Periodontol. 2000 2000, 22, 104-132. [CrossRef]

72. Harmouche, L.; Courval, A.; Mathieu, A.; Petit, C.; Huck, O.; Severac, F.; Davideau, J.-L. Impact of tooth-related factors on photodynamic therapy effectiveness during active periodontal therapy: A 6-months split-mouth randomized clinical trial. Photodiagnosis Photodyn. 2019, 190-194. [CrossRef]

73. Abdul Rahman, N.; Nickles, K.; Gallenbach, K.; Dannewitz, B.; Ramich, T.; Scharf, S.; Röllke, L.; Schacher, B.; Eickholz, P. Five-year stability of clinical attachment after regenerative treatment of infrabony defects compared to controls. J. Clin. Periodontol. 2019, 46, 650-658. [CrossRef]

74. Da Rocha, H.A.J.; Silva, C.F.; Santiago, F.L.; Martins, L.G.; Dias, P.C.; De Magalhães, D. Local Drug Delivery Systems in the Treatment of Periodontitis: A Literature Review. J. Int. Acad. Periodontol. 2015, 17, 82-90.

75. Morand, D.N.; Davideau, J.-L.; Clauss, F.; Jessel, N.; Tenenbaum, H.; Huck, O. Cytokines during periodontal wound healing: Potential application for new therapeutic approach. Oral Dis. 2017, 23, 300-311. [CrossRef]

76. Batool, F.; Strub, M.; Petit, C.; Bugueno, I.M.; Bornert, F.; Clauss, F.; Huck, O.; Kuchler-Bopp, S.; Benkirane-Jessel, N. Periodontal Tissues, Maxillary Jaw Bone, and Tooth Regeneration Approaches: From Animal Models Analyses to Clinical Applications. Nanomaterials 2018, 8, 337. [CrossRef]

77. Petit, C.; Batool, F.; Bugueno, I.M.; Schwinté, P.; Benkirane-Jessel, N.; Huck, O. Contribution of Statins towards Periodontal Treatment: A Review. Mediat. Inflamm. 2019, 2019, 6367402. [CrossRef]

78. Sah, A.K.; Dewangan, M.; Suresh, P.K. Potential of chitosan-based carrier for periodontal drug delivery. Colloids Surf. B: Biointerfaces 2019, 178, 185-198. [CrossRef]

79. Yar, M.; Farooq, A.; Shahzadi, L.; Khan, A.S.; Mahmood, N.; Rauf, A.; Chaudhry, A.A.; Rehman, I.U. Novel meloxicam releasing electrospun polymer/ceramic reinforced biodegradable membranes for periodontal regeneration applications. Mater. Sci. Eng. C Mater. Biol. Appl. 2016, 64, 148-156. [CrossRef]

80. Kamal, T.; Khan, S.B.; Haider, S.; Alghamdi, Y.G.; Asiri, A.M. Thin layer chitosan-coated cellulose filter paper as substrate for immobilization of catalytic cobalt nanoparticles. Int. J. Biol. Macromol. 2017, 104, 56-62. [CrossRef]

81. Işılay Özdoğan, A.; Akca, G.; Şenel, S. Development and in vitro evaluation of chitosan based system for local delivery of atorvastatin for treatment of periodontitis. Eur. J. Pharm. Sci. 2018, 124, 208-216. [CrossRef]

82. Ganguly, A.; Ian, C.K.; Sheshala, R.; Sahu, P.S.; Al-Waeli, H.; Meka, V.S. Application of diverse natural polymers in the design of oral gels for the treatment of periodontal diseases. J. Mater. Sci. Mater. Med. 2017, 28, 39. [CrossRef]

83. Özdoğan, A.I.; İlarslan, Y.D.; Kösemehmetoğlu, K.; Akca, G.; Kutlu, H.B.; Comerdov, E.; Iskit, A.B.; Şenel, S. In vivo evaluation of chitosan based local delivery systems for atorvastatin in treatment of periodontitis. Int. J. Pharm. 2018, 550, 470-476. [CrossRef]

84. Madi, M.; Pavlic, V.; Samy, W.; Alagl, A. The anti-inflammatory effect of locally delivered nano-doxycycline gel in therapy of chronic periodontitis. Acta Odontol. Scand. 2018, 76, 71-76. [CrossRef] 
85. Khan, G.; Yadav, S.K.; Patel, R.R.; Nath, G.; Bansal, M.; Mishra, B. Development and Evaluation of Biodegradable Chitosan Films of Metronidazole and Levofloxacin for the Management of Periodontitis. Aaps Pharmscitech 2016, 17, 1312-1325. [CrossRef]

86. Lin, C.-Y.; Tseng, K.-S.; Liu, J.-M.; Chuang, H.-C.; Lien, C.-H.; Chen, Y.-C.; Lai, C.-Y.; Yu, C.-P.; Hsu, R.-J. Increased Risk of Ulcerative Colitis in Patients with Periodontal Disease: A Nationwide Population-Based Cohort Study. Int. J. Env. Res. Public Health 2018, 15, 2602. [CrossRef]

87. Kilicarslan, M.; Gumustas, M.; Yildiz, S.; Baykara, T. Preparation and characterization of chitosan-based spray-dried microparticles for the delivery of clindamycin phosphate to periodontal pockets. Curr. Drug Deliv. 2014, 11, 98-111. [CrossRef]

88. Chang, P.-C.; Chao, Y.-C.; Hsiao, M.-H.; Chou, H.-S.; Jheng, Y.-H.; Yu, X.-H.; Lee, N.; Yang, C.; Liu, D.-M. Inhibition of Periodontitis Induction Using a Stimuli-Responsive Hydrogel Carrying Naringin. J. Periodontol. 2017, 88, 190-196. [CrossRef]

89. Barreras, U.S.; Méndez, F.T.; Martínez, R.E.M.; Valencia, C.S.; Rodríguez, P.R.M.; Rodríguez, J.P.L. Chitosan nanoparticles enhance the antibacterial activity of chlorhexidine in collagen membranes used for periapical guided tissue regeneration. Mater. Sci. Eng. C Mater. Biol. Appl. 2016, 58, 1182-1187. [CrossRef]

90. Ferrand, A.; Eap, S.; Richert, L.; Lemoine, S.; Kalaskar, D.; Demoustier-Champagne, S.; Atmani, H.; Mély, Y.; Fioretti, F.; Schlatter, G.; et al. Osteogenetic properties of electrospun nanofibrous PCL scaffolds equipped with chitosan-based nanoreservoirs of growth factors. Macromol. Biosci. 2014, 14, 45-55. [CrossRef]

91. Issa, J.P.M.; do Nascimento, C.; Bentley, M.V.L.B.; Del Bel, E.A.; Iyomasa, M.M.; Sebald, W.; de Albuquerque, R.F. Bone repair in rat mandible by rhBMP-2 associated with two carriers. Micron 2008, 39, 373-379. [CrossRef]

92. Seol, Y.-J.; Lee, J.-Y.; Park, Y.-J.; Lee, Y.-M.; Young-Ku, N.; Rhyu, I.-C.; Lee, S.-J.; Han, S.-B.; Chung, C.-P. Chitosan sponges as tissue engineering scaffolds for bone formation. Biotechnol. Lett. 2004, 26, 1037-1041. [CrossRef]

93. Mohammadi, R.; Amini, K. Guided bone regeneration of mandibles using chitosan scaffold seeded with characterized uncultured omental adipose-derived stromal vascular fraction: An animal study. Int. J. Oral Maxillofac Implant. 2015, 30, 216-222. [CrossRef]

94. Xu, F.; Wu, Y.; Zhang, Y.; Yin, P.; Fang, C.; Wang, J. Influence of in vitro differentiation status on the in vivo bone regeneration of cell/chitosan microspheres using a rat cranial defect model. J. Biomater. Sci. Polym. Ed. 2019, 30, 1008-1025. [CrossRef]

95. Danilchenko, S.N.; Kalinkevich, O.V.; Pogorelov, M.V.; Kalinkevich, A.N.; Sklyar, A.M.; Kalinichenko, T.G.; Ilyashenko, V.Y.; Starikov, V.V.; Bumeyster, V.I.; Sikora, V.Z.; et al. Characterization and in vivo evaluation of chitosan-hydroxyapatite bone scaffolds made by one step coprecipitation method. J. Biomed. Mater. Res. Part. A 2011, 96A, 639-647. [CrossRef]

96. Zhang, X.; Zhu, L.; Lv, H.; Cao, Y.; Liu, Y.; Xu, Y.; Ye, W.; Wang, J. Repair of rabbit femoral condyle bone defects with injectable nanohydroxyapatite/chitosan composites. J. Mater. Sci. Mater. Med. 2012, 23, 1941-1949. [CrossRef]

97. Gaihre, B.; Jayasuriya, A.C. Comparative investigation of porous nano-hydroxyapaptite/chitosan, nano-zirconia/chitosan and novel nano-calcium zirconate/chitosan composite scaffolds for their potential applications in bone regeneration. Mater. Sci. Eng. C Mater. Biol. Appl. 2018, 91, 330-339. [CrossRef]

98. Cho, B.C.; Chung, H.Y.; Lee, D.G.; Yang, J.D.; Park, J.W.; Roh, K.H.; Kim, G.U.; Lee, D.S.; Kwon, I.C.; Bae, E.H.; et al. The effect of chitosan bead encapsulating calcium sulfate as an injectable bone substitute on consolidation in the mandibular distraction osteogenesis of a dog model. J. Oral Maxillofac. Surg. 2005, 63, 1753-1764. [CrossRef]

99. Pattnaik, S.; Nethala, S.; Tripathi, A.; Saravanan, S.; Moorthi, A.; Selvamurugan, N. Chitosan scaffolds containing silicon dioxide and zirconia nano particles for bone tissue engineering. Int. J. Biol. Macromol. 2011, 49, 1167-1172. [CrossRef]

100. Shokri, S.; Movahedi, B.; Rafieinia, M.; Salehi, H. A new approach to fabrication of Cs/BG/CNT nanocomposite scaffold towards bone tissue engineering and evaluation of its properties. Appl. Surf. Sci. 2015, 357, 1758-1764. [CrossRef]

101. Kucharska, M.; Butruk, B.; Walenko, K.; Brynk, T.; Ciach, T. Fabrication of in-situ foamed chitosan/ $\beta$-TCP scaffolds for bone tissue engineering application. Mater. Lett. 2012, 85, 124-127. [CrossRef] 
102. Cheng, G.; Li, Z.; Wan, Q.; Lv, K.; Li, D.; Xing, X.; Li, Z. A novel animal model treated with tooth extraction to repair the full-thickness defects in the mandible of rabbits. J. Surg. Res. 2015, 194, 706-716. [CrossRef]

103. Chang, H.-H.; Wang, Y.-L.; Chiang, Y.-C.; Chen, Y.-L.; Chuang, Y.-H.; Tsai, S.-J.; Heish, K.-H.; Lin, F.-H.; Lin, C.-P. A Novel Chitosan- $\gamma$ PGA Polyelectrolyte Complex Hydrogel Promotes Early New Bone Formation in the Alveolar Socket Following Tooth Extraction. PloS ONE 2014, 9, e92362. [CrossRef]

104. Fan, J.; Park, H.; Lee, M.K.; Bezouglaia, O.; Fartash, A.; Kim, J.; Aghaloo, T.; Lee, M. Adipose-derived stem cells and BMP-2 delivery in chitosan-based $3 \mathrm{D}$ constructs to enhance bone regeneration in a rat mandibular defect model. Tissue Eng. Part. A 2014, 20, 2169-2179. [CrossRef]

105. Pourhaghgouy, M.; Zamanian, A.; Shahrezaee, M.; Masouleh, M.P. Physicochemical properties and bioactivity of freeze-cast chitosan nanocomposite scaffolds reinforced with bioactive glass. Mater. Sci. Eng. C Mater. Biol. Appl. 2016, 58, 180-186. [CrossRef]

106. Nazemi, K.; Azadpour, P.; Moztarzadeh, F.; Urbanska, A.M.; Mozafari, M. Tissue-engineered chitosan/bioactive glass bone scaffolds integrated with PLGA nanoparticles: A therapeutic design for on-demand drug delivery. Mater. Lett. 2015, 138, 16-20. [CrossRef]

107. Venkatesan, J.; Ryu, B.; Sudha, P.N.; Kim, S.-K. Preparation and characterization of chitosan-carbon nanotube scaffolds for bone tissue engineering. Int. J. Biol. Macromol. 2012, 50, 393-402. [CrossRef]

108. Saravanan, S.; Sameera, D.K.; Moorthi, A.; Selvamurugan, N. Chitosan scaffolds containing chicken feather keratin nanoparticles for bone tissue engineering. Int. J. Biol. Macromol. 2013, 62, 481-486. [CrossRef]

109. Maglione, M.; Spano, S.; Ruaro, M.E.; Salvador, E.; Zanconati, F.; Tromba, G.; Turco, G. In vivo evaluation of chitosan-glycerol gel scaffolds seeded with stem cells for full-thickness mandibular bone regeneration. J. Oral Sci. 2017, 59, 225-232. [CrossRef]

110. Saravanan, S.; Vimalraj, S.; Anuradha, D. Chitosan based thermoresponsive hydrogel containing graphene oxide for bone tissue repair. Biomed. Pharm. 2018, 107, 908-917. [CrossRef]

111. Keller, L.; Pijnenburg, L.; Idoux-Gillet, Y.; Bornert, F.; Benameur, L.; Tabrizian, M.; Auvray, P.; Rosset, P.; Gonzalo-Daganzo, R.M.; Barrena, E.G.; et al. Preclinical safety study of a combined therapeutic bone wound dressing for osteoarticular regeneration. Nat. Commun. 2019, 10, 2156. [CrossRef]

112. Jayakumar, R.; Ramachandran, R.; Sudheesh Kumar, P.T.; Divyarani, V.V.; Srinivasan, S.; Chennazhi, K.P.; Tamura, H.; Nair, S.V. Fabrication of chitin-chitosan/nano ZrO2 composite scaffolds for tissue engineering applications. Int. J. Biol. Macromol. 2011, 49, 274-280. [CrossRef]

113. Park, J.-S.; Choi, S.-H.; Moon, I.-S.; Cho, K.-S.; Chai, J.-K.; Kim, C.-K. Eight-week histological analysis on the effect of chitosan on surgically created one-wall intrabony defects in beagle dogs. J. Clin. Periodontol. 2003, 30, 443-453. [CrossRef]

114. Eap, S.; Ferrand, A.; Schiavi, J.; Keller, L.; Kokten, T.; Fioretti, F.; Mainard, D.; Ladam, G.; Benkirane-Jessel, N. Collagen implants equipped with 'fish scale'-like nanoreservoirs of growth factors for bone regeneration. Nanomed. (Lond) 2014, 9, 1253-1261. [CrossRef]

115. Zhang, Y.; Shi, B.; Li, C.; Wang, Y.; Chen, Y.; Zhang, W.; Luo, T.; Cheng, X. The synergetic bone-forming effects of combinations of growth factors expressed by adenovirus vectors on chitosan/collagen scaffolds. J. Control. Release 2009, 136, 172-178. [CrossRef]

116. Zhang, Q.; Hubenak, J.; Iyyanki, T.; Alred, E.; Turza, K.C.; Davis, G.; Chang, E.I.; Branch-Brooks, C.D.; Beahm, E.K.; Butler, C.E. Engineering vascularized soft tissue flaps in an animal model using human adipose-derived stem cells and VEGF+PLGA/PEG microspheres on a collagen-chitosan scaffold with a flow-through vascular pedicle. Biomaterials 2015, 73, 198-213. [CrossRef]

117. Shi, S.; Cheng, X.; Wang, J.; Zhang, W.; Peng, L.; Zhang, Y. RhBMP-2 microspheres-loaded chitosan/collagen scaffold enhanced osseointegration: An experiment in dog. J. Biomater. Appl. 2009, 23, 331-346.

118. Elango, J.; Saravanakumar, K.; Rahman, S.U.; Henrotin, Y.; Regenstein, J.M.; Wu, W.; Bao, B. Chitosan-Collagen 3D Matrix Mimics Trabecular Bone and Regulates RANKL-Mediated Paracrine Cues of Differentiated Osteoblast and Mesenchymal Stem Cells for Bone Marrow Macrophage-Derived Osteoclastogenesis. Biomolecules 2019, 9, 173. [CrossRef]

119. Ansarizadeh, M.; Mashayekhan, S.; Saadatmand, M. Fabrication, modeling and optimization of lyophilized advanced platelet rich fibrin in combination with collagen-chitosan as a guided bone regeneration membrane. Int. J. Biol. Macromol. 2019, 125, 383-391. [CrossRef] 
120. Sowjanya, J.A.; Singh, J.; Mohita, T.; Sarvanan, S.; Moorthi, A.; Srinivasan, N.; Selvamurugan, N. Biocomposite scaffolds containing chitosan/alginate/nano-silica for bone tissue engineering. Colloids Surf. B Biointerfaces 2013, 109, 294-300. [CrossRef]

121. Kim, H.-L.; Jung, G.-Y.; Yoon, J.-H.; Han, J.-S.; Park, Y.-J.; Kim, D.-G.; Zhang, M.; Kim, D.-J. Preparation and characterization of nano-sized hydroxyapatite/alginate/chitosan composite scaffolds for bone tissue engineering. Mater. Sci. Eng. C Mater. Biol. Appl. 2015, 54, 20-25. [CrossRef]

122. Jin, H.-H.; Kim, D.-H.; Kim, T.-W.; Shin, K.-K.; Jung, J.S.; Park, H.-C.; Yoon, S.-Y. In vivo evaluation of porous hydroxyapatite/chitosan-alginate composite scaffolds for bone tissue engineering. Int. J. Biol. Macromol. 2012, 51, 1079-1085. [CrossRef]

123. Florczyk, S.J.; Leung, M.; Li, Z.; Huang, J.I.; Hopper, R.A.; Zhang, M. Evaluation of three-dimensional porous chitosan-alginate scaffolds in rat calvarial defects for bone regeneration applications. J. Biomed. Mater. Res. A 2013, 101, 2974-2983. [CrossRef]

124. Teimouri, A.; Ebrahimi, R.; Emadi, R.; Beni, B.H.; Chermahini, A.N. Nano-composite of silk fibroin-chitosan/Nano $\mathrm{ZrO} 2$ for tissue engineering applications: Fabrication and morphology. Int. J. Biol. Macromol. 2015, 76, 292-302. [CrossRef]

125. Lima, P.A.L.; Resende, C.X.; de Almeida Soares, G.D.; Anselme, K.; Almeida, L.E. Preparation, characterization and biological test of 3D-scaffolds based on chitosan, fibroin and hydroxyapatite for bone tissue engineering. Mater. Sci. Eng. C Mater. Biol. Appl. 2013, 33, 3389-3395. [CrossRef]

126. Tong, S.; Xu, D.-P.; Liu, Z.-M.; Du, Y.; Wang, X.-K. Synthesis of and in vitro and in vivo evaluation of a novel TGF- $31-S F-C S$ three-dimensional scaffold for bone tissue engineering. Int. J. Mol. Med. 2016, 38, 367-380. [CrossRef]

127. Niu, X.; Fan, Y.; Liu, X.; Li, X.; Li, P.; Wang, J.; Sha, Z.; Feng, Q. Repair of bone defect in femoral condyle using microencapsulated chitosan, nanohydroxyapatite/collagen and poly(L-lactide)-based microsphere-scaffold delivery system. Artif. Organs 2011, 35, E119-E128. [CrossRef]

128. Sainitya, R.; Sriram, M.; Kalyanaraman, V.; Dhivya, S.; Saravanan, S.; Vairamani, M.; Sastry, T.P.; Selvamurugan, N. Scaffolds containing chitosan/carboxymethyl cellulose/mesoporous wollastonite for bone tissue engineering. Int. J. Biol. Macromol. 2015, 80, 481-488. [CrossRef]

129. Miranda, S.C.C.C.; Silva, G.A.B.; Mendes, R.M.; Abreu, F.A.M.; Caliari, M.V.; Alves, J.B.; Goes, A.M. Mesenchymal stem cells associated with porous chitosan-gelatin scaffold: A potential strategy for alveolar bone regeneration. J. Biomed. Mater. Res. Part. A 2012, 100A, 2775-2786. [CrossRef]

130. Olad, A.; Farshi Azhar, F. The synergetic effect of bioactive ceramic and nanoclay on the properties of chitosan-gelatin/nanohydroxyapatite-montmorillonite scaffold for bone tissue engineering. Ceram. Int. 2014, 40, 10061-10072. [CrossRef]

131. Kavya, K.C.; Jayakumar, R.; Nair, S.; Chennazhi, K.P. Fabrication and characterization of chitosan/gelatin/nSiO2 composite scaffold for bone tissue engineering. Int. J. Biol. Macromol. 2013, 59, 255-263. [CrossRef]

132. Serra, I.R.; Fradique, R.; Vallejo, M.C.S.; Correia, T.R.; Miguel, S.P.; Correia, I.J. Production and characterization of chitosan/gelatin/ $\beta$-TCP scaffolds for improved bone tissue regeneration. Mater. Sci. Eng. C Mater. Biol. Appl. 2015, 55, 592-604. [CrossRef]

133. Acevedo, C.A.; Olguín, Y.; Briceño, M.; Forero, J.C.; Osses, N.; Díaz-Calderón, P.; Jaques, A.; Ortiz, R. Design of a biodegradable UV-irradiated gelatin-chitosan/nanocomposed membrane with osteogenic ability for application in bone regeneration. Mater. Sci. Eng. C Mater. Biol. Appl. 2019, 99, 875-886. [CrossRef]

134. Maji, K.; Dasgupta, S.; Kundu, B.; Bissoyi, A. Development of gelatin-chitosan-hydroxyapatite based bioactive bone scaffold with controlled pore size and mechanical strength. J. Biomater. Sci. Polym. Ed. 2015, 26, 1190-1209. [CrossRef]

135. Puvaneswary, S.; Talebian, S.; Raghavendran, H.B.; Murali, M.R.; Mehrali, M.; Afifi, A.M.; Kasim, N.H.B.A.; Kamarul, T. Fabrication and in vitro biological activity of $\beta$ TCP-Chitosan-Fucoidan composite for bone tissue engineering. Carbohydr. Polym. 2015, 134, 799-807. [CrossRef]

136. Jing, X.; Mi, H.-Y.; Peng, J.; Peng, X.-F.; Turng, L.-S. Electrospun aligned poly(propylene carbonate) microfibers with chitosan nanofibers as tissue engineering scaffolds. Carbohydr. Polym. 2015, 117, 941-949. [CrossRef]

137. Zhang, S.; Prabhakaran, M.P.; Qin, X.; Ramakrishna, S. Biocomposite scaffolds for bone regeneration: Role of chitosan and hydroxyapatite within poly-3-hydroxybutyrate-co-3-hydroxyvalerate on mechanical properties and in vitro evaluation. J. Mech. Behav. Biomed. Mater. 2015, 51, 88-98. [CrossRef] 
138. Yao, Q.; Li, W.; Yu, S.; Ma, L.; Jin, D.; Boccaccini, A.R.; Liu, Y. Multifunctional chitosan/polyvinyl pyrrolidone/45S5 Bioglass®scaffolds for MC3T3-E1 cell stimulation and drug release. Mater. Sci. Eng. C Mater. Biol. Appl. 2015, 56, 473-480. [CrossRef]

139. Sajesh, K.M.; Jayakumar, R.; Nair, S.V.; Chennazhi, K.P. Biocompatible conducting chitosan/polypyrrole-alginate composite scaffold for bone tissue engineering. Int. J. Biol. Macromol. 2013, 62, 465-471. [CrossRef]

140. Pon-On, W.; Charoenphandhu, N.; Teerapornpuntakit, J.; Thongbunchoo, J.; Krishnamra, N.; Tang, I.-M. Mechanical properties, biological activity and protein controlled release by poly(vinyl alcohol)-bioglass/chitosan-collagen composite scaffolds: A bone tissue engineering applications. Mater. Sci. Eng. C Mater. Biol. Appl. 2014, 38, 63-72. [CrossRef]

141. Peng, L.; Zhou, Y.; Lu, W.; Zhu, W.; Li, Y.; Chen, K.; Zhang, G.; Xu, J.; Deng, Z.; Wang, D. Characterization of a novel polyvinyl alcohol/chitosan porous hydrogel combined with bone marrow mesenchymal stem cells and its application in articular cartilage repair. BMC Musculoskelet. Disord. 2019, 20, 257. [CrossRef]

142. De la Riva, B.; Nowak, C.; Sánchez, E.; Hernández, A.; Schulz-Siegmund, M.; Pec, M.K.; Delgado, A.; Evora, C. VEGF-controlled release within a bone defect from alginate/chitosan/PLA-H scaffolds. Eur. J. Pharm. Biopharm. 2009, 73, 50-58. [CrossRef]

143. Keller, L.; Offner, D.; Schwinté, P.; Morand, D.; Wagner, Q.; Gros, C.; Bornert, F.; Bahi, S.; Musset, A.-M.; Benkirane-Jessel, N.; et al. Active Nanomaterials to Meet the Challenge of Dental Pulp Regeneration. Mater. (Basel) 2015, 8, 7461-7471. [CrossRef]

144. Zein, N.; Harmouch, E.; Lutz, J.-C.; Fernandez De Grado, G.; Kuchler-Bopp, S.; Clauss, F.; Offner, D.; Hua, G.; Benkirane-Jessel, N.; Fioretti, F. Polymer-Based Instructive Scaffolds for Endodontic Regeneration. Mater. (Basel) 2019, 12, 2347. [CrossRef]

145. Liao, F.; Chen, Y.; Li, Z.; Wang, Y.; Shi, B.; Gong, Z.; Cheng, X. A novel bioactive three-dimensional beta-tricalcium phosphate/chitosan scaffold for periodontal tissue engineering. J. Mater. Sci. Mater. Med. 2010, 21, 489-496. [CrossRef]

146. Albuquerque, M.T.P.; Valera, M.C.; Nakashima, M.; Nör, J.E.; Bottino, M.C. Tissue-engineering-based strategies for regenerative endodontics. J. Dent. Res. 2014, 93, 1222-1231. [CrossRef]

147. Bordini, E.A.F.; Cassiano, F.B.; Silva, I.S.P.; Usberti, F.R.; Anovazzi, G.; Pacheco, L.E.; Pansani, T.N.; Leite, M.L.; Hebling, J.; de Souza Costa, C.A.; et al. Synergistic potential of 1 $\alpha, 25$-dihydroxyvitamin D3 and calcium-aluminate-chitosan scaffolds with dental pulp cells. Clin. Oral Investig. 2019, 1-12. [CrossRef]

148. Ducret, M.; Montembault, A.; Josse, J.; Pasdeloup, M.; Celle, A.; Benchrih, R.; Mallein-Gerin, F.; Alliot-Licht, B.; David, L.; Farges, J.-C. Design and characterization of a chitosan-enriched fibrin hydrogel for human dental pulp regeneration. Dent. Mater. 2019, 35, 523-533. [CrossRef]

149. Zhu, N.; Chatzistavrou, X.; Ge, L.; Qin, M.; Papagerakis, P.; Wang, Y. Biological properties of modified bioactive glass on dental pulp cells. J. Dent. 2019, 83, 18-26. [CrossRef]

150. Loyola-Rodríguez, J.P.; Torres-Méndez, F.; Espinosa-Cristobal, L.F.; García-Cortes, J.O.; Loyola-Leyva, A.; González, F.J.; Soto-Barreras, U.; Nieto-Aguilar, R.; Contreras-Palma, G. Antimicrobial activity of endodontic sealers and medications containing chitosan and silver nanoparticles against Enterococcus faecalis. J. Appl. Biomater. Funct. Mater. 2019, 17, 2280800019851771. [CrossRef]

(C) 2019 by the authors. Licensee MDPI, Basel, Switzerland. This article is an open access article distributed under the terms and conditions of the Creative Commons Attribution (CC BY) license (http://creativecommons.org/licenses/by/4.0/). 